\section{Differential Protein Analysis of Pecan Hardwood Cuttings}

Fan Cao

College of Forestry, Nanjing Forestry University, Nanjing 210037, China

Xinwang Wang

U.S. Department of Agriculture, Agricultural Research Service, Pecan Breeding and Germplasm Repository, 10200 FM 50, Somerville, TX 77879

Zhuangzhuang Liu

College of Forestry, Nanjing Forestry University, Nanjing 210037, China

Yongrong Li

Nanjing Green Universe Pecan Science \& Technology Co., Ltd., Nanjing 210037, China

Fangren Peng ${ }^{1}$

College of Forestry, Nanjing Forestry University, Nanjing 210037, China

Additional index words. anatomy, adventitious root formation, Carya illinoinensis, twodimensional electrophoresis

Abstract. Pecan cuttings are difficult for rooting. This study describes the pecan hardwood rooting process based on anatomic characteristics to understand root formation mechanisms of pecan cuttings. The expressed proteins of different periods during the adventitious rooting process of pecan seedling hardwood cuttings were identified and analyzed to evaluate the rooting mechanism. The expressed proteins of pecan cutting seedlings were also compared with other cultivar cuttings during the rooting period. Pecan seedling cuttings were developed at different air and substrate temperatures to induce root formation. Adventitious root formation of pecan hardwood cuttings was described, and the phloem at the base of the prepared cuttings was selected as the sample for the differential protein analysis. The results showed that adventitious root formation of pecan hardwood cuttings was the only product of callus differentiation, which originated from the cells of the cambium or vascular ray parenchyma. Such adventitious root primordia were developed from those calluses that formed the regenerative structure, and the expressed proteins during the adventitious rooting of pecan hardwood cutting were identified and analyzed by matrix-assisted laser desorption ionization-time of flight-mass spectrometry (MALDI-TOF-MS) to evaluate the rooting mechanism. Eight differentially expressed proteins were found in the rooting periods, and 15 differential proteins were found by comparing pecan cutting types, which were analyzed by peptide mass fingerprinting homology. The results show that the primordial cells were differentiated from the meristematic cells. Furthermore, the differentially expressed proteins contained energy metabolism proteins, adversity stress proteins, and signal transmission proteins. The energy metabolism-related proteins were adenosine triphosphate (ATP) synthase, photosynthesis-related proteins, and enolase. The adversity-stress proteins containing heat shock-related proteins and signal transmission proteins were mainly cytochrome enzymes and heme-binding proteins. Adventitious root formation of pecan cultivar hardwood cuttings was difficult. More trials should be performed from the potential aspects of high defensive protection and phloem morphologic structure.

Pecan [Carya illinoinensis (Wangenh.) K. Koch], a member of the Juglandaceae family, is native to North America. It is popular worldwide as an important multipurpose tree

\footnotetext{
Received for publication 26 Dec. 2018. Accepted for publication 11 Apr. 2019.

This project was supported by Jiangsu Forestry Science and Technology Innovation and Promotion Project (LYKJ[2018]05-1) and Priority Academic Program Development of Jiangsu Higher Education Institutions (PAPD).

${ }^{1}$ Corresponding author. E-mail: frpeng@njfu. edu.cn.
}

species for both its economic and ecologic benefits (Wood, 2001). Although it was introduced into China at the end of 19th century, it still does not form a large-scale commercial industry in that country based on a number of limitations (Peng et al., 2012). During the past 10 years, renewed interest has been given to clonal propagation research in China because of the rapidly increasing demands of the international pecan market (Zhang et al., 2015c). However, the hardwood cutting propagation technique is difficult.

A rooting method for pecan cuttings by treating with root-inducing chemicals, such as lanolin mixtures of indole butyric acid, was first reported in the early 19th century (Smith and Romberg, 1939). Since then, new treatment protocols have been explored (Allan et al., 1980; Brutsch et al., 1969; Fouad et al., 1992; Smith and Chiu, 1980; Wolstenholme and Allan, 1975) to induce roots for pecan stem cuttings. To understand adventitious root formation, the anatomy of roots for pecan stem cuttings has been studied (Brutsch et al., 1977; Fayek et al., 1994). During the past 5 years, the studies of root formation for pecan hardwood cuttings increased. For example, cuttings were treated with varying concentrations of different auxins and different combinations of media and ambient temperatures, which showed that auxin and substrate/air temperature differences were indispensable in the process of adventitious root formation for pecan hardwood cuttings (Zhang et al., 2015a). By using such treatment in the appropriate environmental conditions (i.e., external environment temperature, $15^{\circ} \mathrm{C}$; soil temperature, 25 to $30^{\circ} \mathrm{C}$; the best treatment is a concentration of ABT-1 $500 \mathrm{mg} \cdot \mathrm{L}^{-1}$ of rooting after soaking $6 \mathrm{~h}$ ), the rooting rate of pecan hardwood cuttings reached as high as $87 \%$ (Cao et al., 2015). Although significant progress for pecan hardwood cutting techniques has been made, a robust pecan hardwood cutting protocol has not yet been developed and applied successfully in pecan breeding. Furthermore, the materials of this protocol can come from pecan seedlings rather than cultivars. In addition, the rooting mechanism during the process of adventitious root formation for pecan cuttings is unknown.

Compared with native pecan, pecan cultivars vary widely in yield potential, nut quality, date of maturity, tree form, and resistance to insects and diseases. In fact, pecans grown from seeds are not true type because each seedling tree is unique and has extremely variable nut quality. Therefore, to propagate a tree of a given cultivar by traditional grafting, buds or shoots from the parent tree must be grafted onto seedling rootstock. Recent research has indicated that grafting success increased more than $90 \%$ when using cleft graft with a hot cable (Casales et al., 2018). However, pecan rootstocks are produced from open-pollinated seeds, which also affects the presentation of the cultivar scion (Sanderlin, 2015). To achieve the goal of one released cultivar with complete germplasm resource reservation, better cutting and tissue culture methods should be explored. It was postulated that the tissue culture method may result in the cloning of different pecan genotypes. However, the main problem of adventitious root formation still exists - a concern that is not present with the cutting method (CorteOlivares et al., 1990).

This study describes the pecan hardwood rooting process based on anatomic characteristics to understand the root formation mechanism of pecan cuttings. The expressed proteins of different periods during the adventitious rooting process of pecan seedling 
hardwood cutting were identified and analyzed to evaluate the rooting mechanism, and the different cutting materials from the pecan seedling and cultivar were compared in the differentially expressed proteins in key rooting periods based on the former observation. The results help to summarize the key factors for rooting of pecan cuttings and provide a reference for pecan cultivar cutting technique research.

\section{Materials and Methods}

Plant material. The experiment was implemented at a pecan orchard in subtropical Zhang Temple village, Jiangsu, China. The annual average temperature is $15.6{ }^{\circ} \mathrm{C}$, with an average daily temperature of more than $10{ }^{\circ} \mathrm{C}$. The annual average relative humidity is $78 \%$, annual average rainfall is $1018.6 \mathrm{~mm}$, and annual average sunshine is $2152 \mathrm{~h}$. The open-pollinated seeds of pecan cultivar Stuart were used to generate seedlings in Nov. 2013. First, the seeds were sterilized in $4 \%$ potassium permanganate for $12 \mathrm{~h}$, then they were soaked in the sink for $2 \mathrm{~d}$ with untreated running tap water at 15 to $20^{\circ} \mathrm{C}$, and then finally they were stratified in moist sand in a sealed plastic bag for about $50 \mathrm{~d}$ at 4 to $8{ }^{\circ} \mathrm{C}$. In Feb. 2013, after being soaked in $500 \mathrm{mg} \cdot \mathrm{L}^{-1}$ gibberellic acid A3 solution for $18 \mathrm{~h}$, the treated pecan seeds were planted into a culturing bed filled with soil substance, a mixture of peat, soil, and

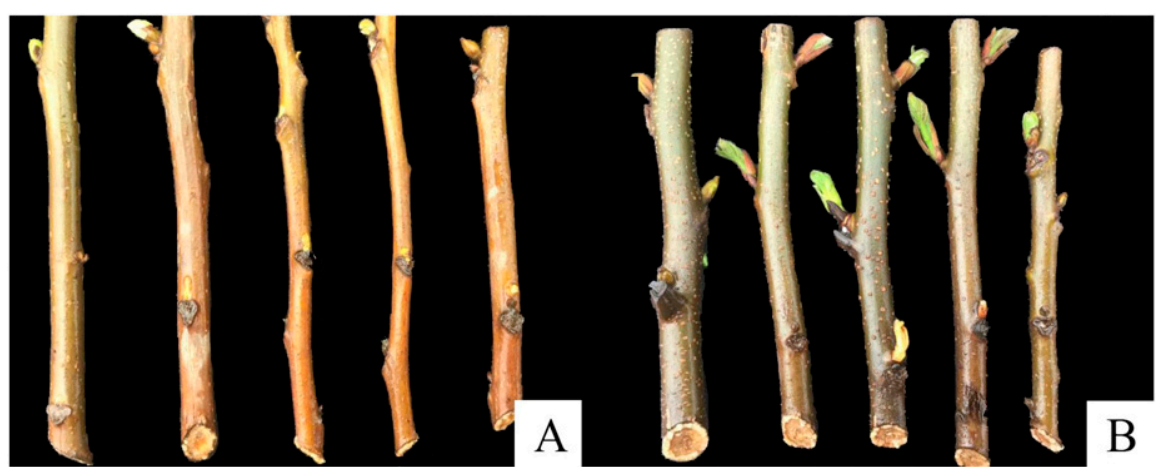

Fig. 1. Pecan hardwood cuttings at key rooting period ( $20 \mathrm{~d}$ after cutting). It was the key period for the induction of adventitious roots. The basal phloem parts of both groups were selected for differential protein analysis. (A) Cutting materials from 'Pawnee'. (B) Cutting materials from 'Stuart' seedling.
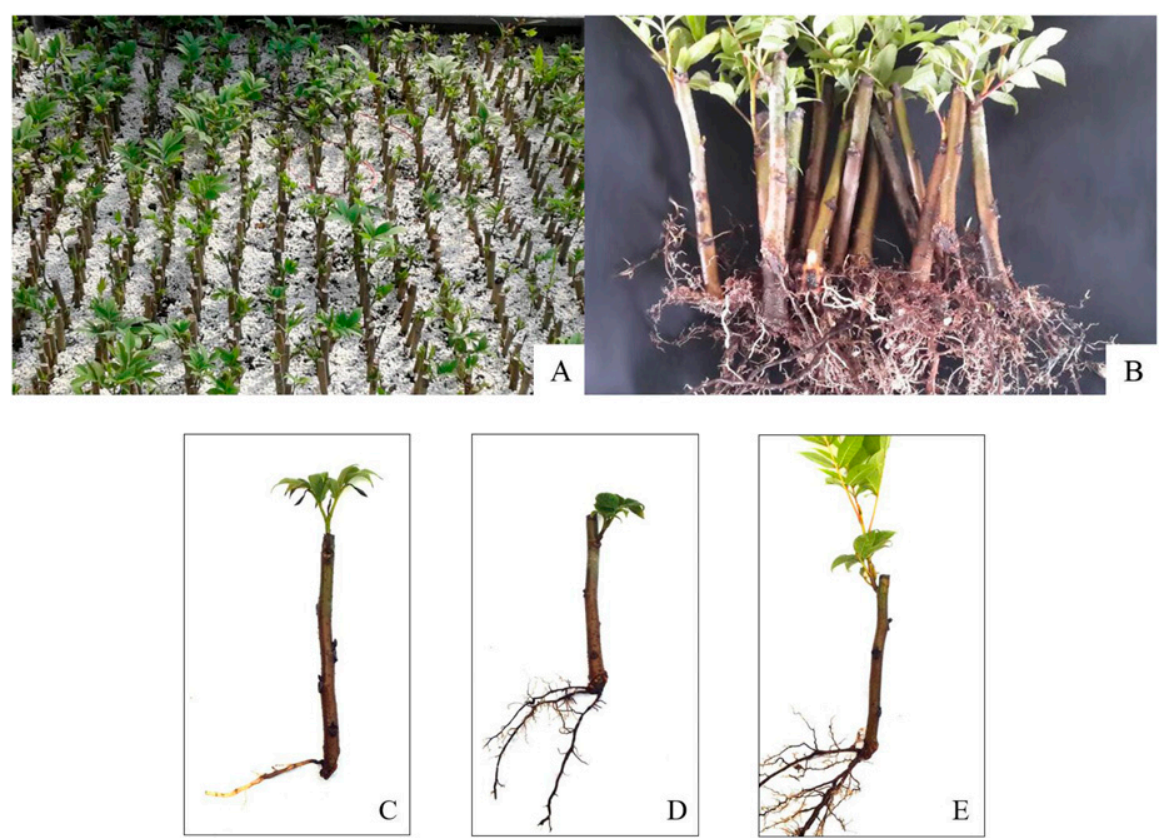

Fig. 2. A field plot of transplanted rooted pecan seedling cuttings. The pecan seedling hardwood cuttings were treated with $500 \mathrm{mg} \cdot \mathrm{L}^{-1} 1$-naphthalene acetic acid $6 \mathrm{~h}$ and planted onto a fixed nursery bed containing peat and perlite substrate with bottom artificial heating. (A) More than $90 \%$ of the pecan seedling cuttings show expanded leaves at $40 \mathrm{~d}$. (B) About $80 \%$ of the pecan seedling cuttings developed adventitious roots at $50 \mathrm{~d}$. (C) Most of the cuttings grew only one adventitious root at the beginning, around $40 \mathrm{~d}$. (D) The root fibrils began to grow when three to five adventitious roots appeared or when the adventitious roots elongated to 2 to $3 \mathrm{~cm}$ at $50 \mathrm{~d}$. (E) After $60 \mathrm{~d}$, with more adventitious roots growing, the branches and leaves on the top of each cutting began to extend and expand. wood ash $(5: 3: 2$ by volume; Shanghai Jizhi Agricultural science and technology Co., Ltd., Shanghai, China). In mid May 2014, 100 seedlings with similar height and ground diameter were transplanted to the test field. In early July 2015 , half the pecan seedlings were selected randomly as rootstock and were grafted using the patch-grafting method (Zhang et al., 2015b) with a 'Pawnee' scion that came from the scion plucking nursery of the orchard. The position of the grafting patch was $\approx 15 \mathrm{~cm}$ aboveground.

In early Dec. 2015, the top part of the 50 grafted 'Pawnee' rootstocks higher than the grafting patch was cut off, and the remaining 50 ungrafted 'Stuart' seedlings were cut to the same height. An excised stick from the same tree was cut at $\approx 8 \mathrm{~cm}$, with a $45^{\circ}$ slope. Cuttings were immersed in moist sand with a relative humidity of $\approx 30 \%$ at room temperature for 2 months, and were used for observation of adventitious root formation and identification of differential proteins during the critical stages of graft rooting.

In Dec. 2016, the upper dormant branches of the grafted and ungrafted young pecan trees were cut into $\approx 8 \mathrm{~cm}$ with a $45^{\circ}$ slope end. Then, in 2015, both cuttings of 'Pawnee' (scion) and 'Stuart' (rootstock) were stored in the same 2-month-reserving environment mentioned earlier and were used for the differential protein analysis of pecan cultivar and seedling cuttings (Fig. 1).

Cutting procedure. The cuttings collected in 2015 and 2016 were used for graft rooting testing in Feb. 2016 and Feb. 2017, respectively, according to previous cutting methods (Cao et al., 2015). Briefly, a solid nursery bed for cutting growth was set up in a greenhouse with a light intensity of 20,000 to 40,000 Lux. The nursery bed stood about $120 \mathrm{~cm}$ away from the ground to maintain rooting substrate air and water permeability. The rooting substrate, containing peat and perlite (a volume ratio of 3:7) (Liaoning Province Jade Source Peat Development Co., Qingyuan, China), was distributed evenly 2 to $3 \mathrm{~cm}$ high on the fine-structure mesh at the bottom of the nursery bed. Then, an electric heating cable at the bottom of substrate was connected to the thermostat so that the temperature of the rooting substrate could be controlled. Finally, the root-induced substrate was placed on the surface 8 to $10 \mathrm{~cm}$ high. The temperature of the lower part of the cuttings was kept at $25 \pm$ $2{ }^{\circ} \mathrm{C}$ and the external air temperature was maintained at $20 \pm 2{ }^{\circ} \mathrm{C}$. All hardwood cuttings were washed by flushing tap water for $12 \mathrm{~h}$, and then the base (length, 2-3 cm) of these cuttings was immersed in a solution containing $500 \mathrm{mg} \cdot \mathrm{L}^{-1}$ 1-naphthaleneacetic acid (NAA) for $6 \mathrm{~h}$. The cuttings were arranged $2 \times 2 \mathrm{~cm}$ apart. Soil media and ambient temperatures were maintained as mentioned earlier. All cuttings were watered with sprinklers every $7 \mathrm{~d}$ to keep the relative humidity at $\approx 60 \%$. In addition, carbendazim solution diluted 800 -fold was sprayed every $10 \mathrm{~d}$ to control bacteria and fungi.

Anatomy observation. In 2016, 10 pecan hardwood cuttings from 'Stuart' seedlings 

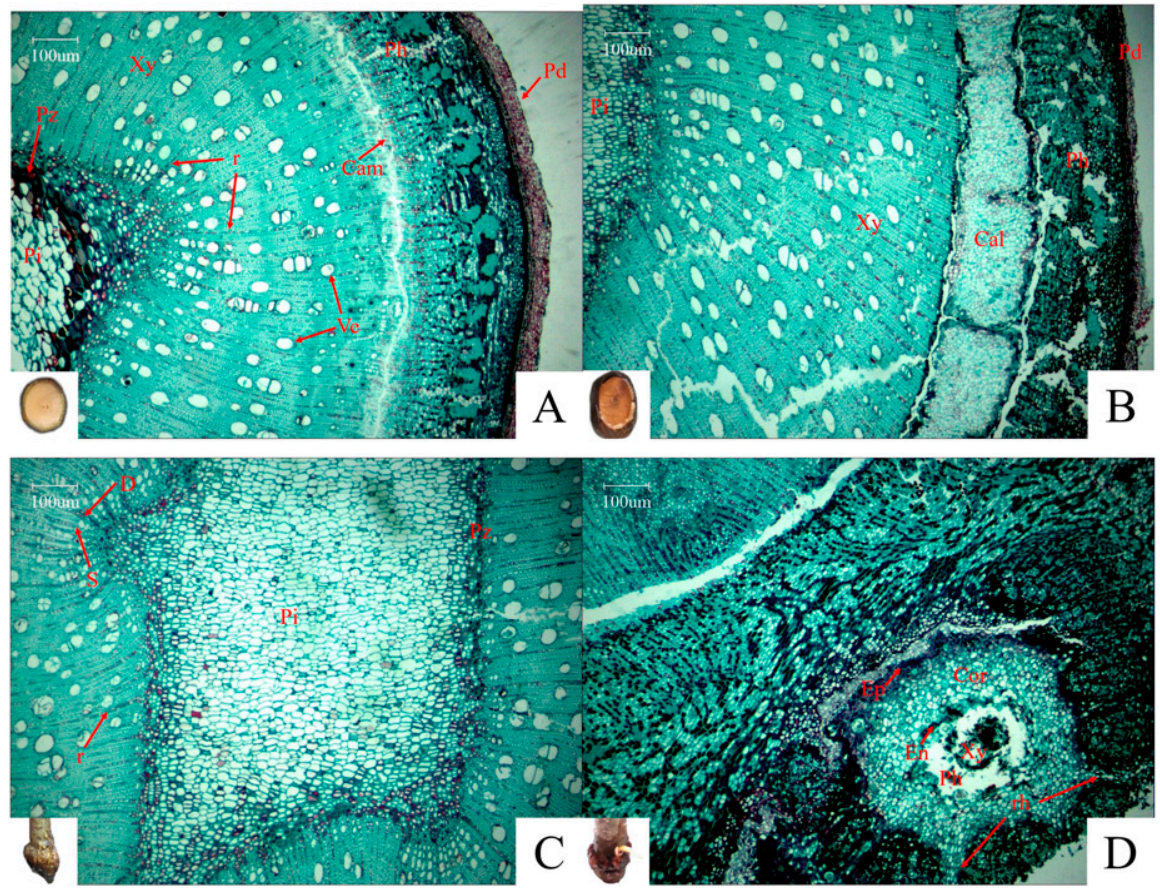

Fig. 3. Stem transection microstructure at different periods after the pecan hardwood cuttings of seedlings were treated with 1-naphthalene acetic acid. (A) Cross-section on day 10. (B) Cross-section on day 20 (C) Diagonal section on day 30. (D) Diagonal section on day 40. Cam, cambium; Cal, callus; Cor, cortex; En, endodermis; Ep, epidermis; Pd, periderm; Ph, phloem; Pi, pith; Pz, perimedullary zone; r, secondary ray (S, single secondary ray; D, double secondary ray); rh, root hair; Ve, vessel; and Xy, xylem.

were collected every $10 \mathrm{~d}$ after cutting. The phloem at the base of the cutting samples was cut into pieces (length, $1 \mathrm{~cm}$ ) and fixed immediately in $70 \%$ alcohol, glacial acetic acid, and formalin for a week. To facilitate the sectioning, samples were softened in $10 \%$ ethylenediamine for 2 months, then dehydrated by a series of increasing alcohol concentrations $(30 \%, 50 \%, 75 \%, 85 \%, 90 \%, 95 \%$, and anhydrous alcohol), cleared through a series of increasing xylene concentrations $(50 \%, 70 \%, 80 \%$, and anhydrous $)$ and embedded in paraffin. Samples were cut into transections (thickness, $10 \mu \mathrm{m}$ ) using a rotary microtome, stained with Safranin Fast Green, and mounted by neutral balsam. Finally, sections were observed using a Nikon light microscope (Nikon Instruments Inc., Shanghai, China) to examine the process of callus development and adventitious root formation.

Differential protein analysis. The phloem at the base of the prepared cuttings mentioned previously was selected as the sample for the differential protein analysis. Protein extraction of the phloem was performed using a modified trichloroacetic acid-acetone precipitation method (Zhou et al., 2016), and the twodimensional gel electrophoresis procedure was referenced from differential protein analysis of pecan graft union formation (Mo et al., 2017). The two-dimensional gel electrophoresis procedure of the different cutting materials was repeated three times. The gel-nitric acid was stained with silver and then scanned using an image scanner (BIO-RAD GS-800) (Mo et al., 2017). The scanned images were analyzed using PDQuest software to calculate the relative volume of different gels. In both experiments, the differential protein spots for which the relative volume multiple was greater than $10 \times$ or less than $0.1 \times$ were analyzed using a MALDI-TOF-MS, and were retrieved in the National Center for Biotechnology Information (NCBInr) plant database to find the most homologous protein and analyze the function.

\section{Results and Discussion}

\section{Adventitious root formation}

Based on the morphologic observations of the treated pecan hardwood cuttings of 'Stuart' seedlings for their morphologic characteristics, the rooting period can be divided into five stages: stage I, callus induction at 10 to $20 \mathrm{~d}$; stage II, callus formation at 21 to 30 $\mathrm{d}$; stage III, beginning of adventitious root formation at 31 to $40 \mathrm{~d}$; stage IV, massive adventitious root formation at 41 to $50 \mathrm{~d}$; and stage $\mathrm{V}$, adventitious root elongation after 51 $\mathrm{d}$. The phloem and xylem of the bottom (the part immersed in the substrates) of cuttings were partly separated, and the callus was induced at about $10 \mathrm{~d}$ (stage I). On day 20 (stage II), the callus began to occur and formed massively. The NAA-treated hardwood cuttings began to form adventitious roots on day 30 (stage III). Starting on day 40 , the cuttings grew with some adventitious roots. By stage IV, it was observed that the skin pores of the base of each cutting had ruptured. The bottom part of the controlled cuttings turned black; the callus turned yellow. After $50 \mathrm{~d}, \approx 80 \%$ of the cuttings were rooted, and it was observed that most of the sprouted hardwood cuttings began to grow leaves (Fig. 2).

Given the observation of the phloem at the base of the pecan hardwood cutting, the segment of the secondary structure from outside to inside was recognized as periderm, cortex, and secondary vascular tissue and pith, respectively (Fig. 3A). Periderm, which consists of the skin pore structure, is composed of a cork layer, cork cambium, and phelloderm. Secondary vascular tissue consists of secondary phloem, vascular cambium, and secondary xylem. Secondary phloem contains a sieve tube, companion cells, phloem parenchyma, phloem ray, and bast fiber. Secondary xylem is the major visible plant tissue in the stem and it consists of catheter, tracheid, wood parenchyma, wood ray, and wood fiber. The inner part of the pecan stem develops vessels that are distributed unevenly and the sizes are varied. The vessel holes near the dense and large pith have more complex holes, and the vessel holes near the cambium are sparse and relatively small. As such, most of them have single vessel holes. In the core of the stem wood is pith, which consists of large, irregular parenchyma cells. The external part, which is far from the pith, contains smallthickness cells that form the boundary. It was observed that all cells from pith to boundary were arranged with radial rays, which connect the primitive cells with the secondary phloem, suggesting these rays play an important role in callus formation of the perimedullary zone. It was also observed that the callus was formed first by the irregular parenchyma cells, which were differentiated from the intersections of the vascular ray and vascular cambium cells. After $20 \mathrm{~d}$, the callus was developed entirely and separated from the xylem at the base of the pecan hardwood cutting (Fig. 3B). Parts of the xylem rays toward the phloem become two columns, and the cells to the side of the pith were still lined as a single ray or a double secondary ray (Fig. 3C). Given our anatomic observations, two types of adventitious root formation were proposed: One is that the callus differentiated to the adventitious roots from the bottom; the other is that the callus divided through the phloem. The adventitious roots of these two rooting types originated from the callus, but the latter is more common. As mentioned earlier in the morphology observation, the phloem at the base $(2-3 \mathrm{~cm})$ began to expand after 4 weeks. When the vascular ray widened and participated in callus formation by parenchyma cell differentiation from the perimedullary zone, the raised and large-area calluses were visible in the cambium of the phloem. It is assumed that the callus squeezes the periderm or even breaks through the phloem or the skin holes, meaning the piercing callus is ready for the differentiation. During callus development, the parenchyma cells underwent continuous fission until they differentiated into various regenerative tissues, such as cortex, xylem, and vascular cambium. Based on our microscopic observations of cutting rooting formation, it was 
found that the parenchyma cells from the regenerative internal structure of the callus restored their meristematic ability. With more cell divisions, the new parenchyma cells in the center became smaller and closer whereas the external cells became deeper in color, which is significantly different from the surrounding cells. These mass parenchyma cells divided continuously until they produced larger, thicker, and colored circular cells, which were designated as the root primordia-originated cells. The apex of the root primordia-originated cells showed a strong differentiative capacity. These differentiated cells grew toward the cortex and gradually formed many meristematic cells. The layer of the peripheral cells protruded as a result of the extrusion of cell division. The division of the cell away from the apex of the root primordia-originated cells lost their meristematic restoration ability gradually, with the thickening of the cell walls. The meristem cells divided continuously for weeks until the final formation of adventitious root primordia. We did not see that any other tissues differentiated into adventitious root primordia in the pecan stem cells.

There were three types of adventitious root formation in the plant cuttings' rooting: cortex-originated rooting type, callusoriginated rooting type, and synthesized type (Davies et al., 1982). It is generally acknowledged that the plant that is difficult for rooting belongs mostly to the callusoriginated rooting type. The cortexoriginated rooting type is the root primordia that lurk mostly in the cortex or xylem outer pith rays. The pith rays, which are connected with the root primordia, are helpful in acquiring nutrition from the myelocyte (Carlson, 1938, 1950). However, one phenomenon of that the adventitious root breaks
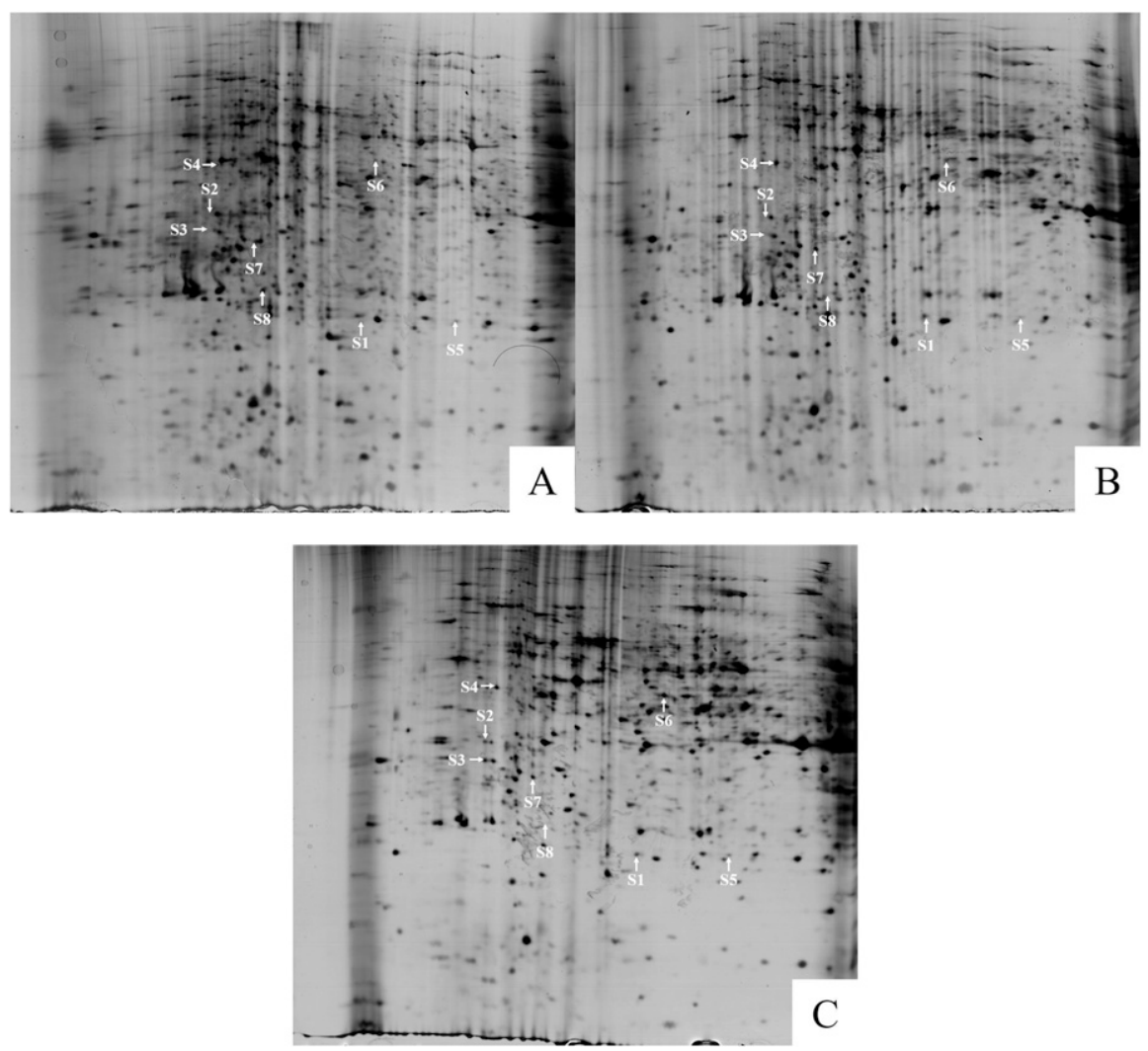

Fig. 4. Representative two-dimensional electrophoresis (2-DE) gel maps of proteins extracted from the pecan seedling hardwood cuttings at different growing periods. 2-DE of protein extracted from rooting region in the hardwood cuttings of Carya illinoinensis at different periods. (A) Samples from day 1. (B) Samples from day 20. (C) Samples from day 40. The most significant difference expressed protein spots (S1-S10), which marked in the maps, were selected for the protein homology analysis. though the phloem is not the cortex-originated rooting type, which is still the synthesized type (Fig. 3D). Based on a series of slice observations, it was found that there was no latent root primordium in pecan cutting stems. The root primordia of pecan hardwood cuttings are the differentiation of the callus cells. Therefore, promoting callus cell differentiation into the root primordia is a key step and is often the same as in other plant species (Bryant and Trueman, 2015; Ma et al., 2015). Many studies have shown that adventitious roots occur more easily when annular sclerenchyma or sclerenchyma discontinuity is absent. According to the primary phloem fiber cell group structure from pecan stem crosscuts of the anatomic structure, it is known that phloem fiber cells have little effect on the inhibition of pecan adventitious root primordia formation, and this gap arrangement does not interfere with the formation of callus and radial growth, coupled with longitudinal callus stretch more easily through the incision. This result was consistent with the observation of more calluses in part of the base and the cutting slit surface. During the rooting process of pecan hardwood cuttings, plant cells may reduce some phenolic compounds, such as a secondary metabolism substance, which could lead to inhibited callus growth, aging, or death to avoid production of adventitious roots (Zhang et al., 2010). In addition, through observation, some cuttings could not differentiate from calluses. As mentioned, the stem anatomy of calluses in the stem does not inhibit differentiation, and this should be another reason.

\section{Differential protein analysis during seedling cutting rooting key periods}

The gel pictures of pecan seedling hardwood cuttings at different growing periods are shown in Fig. 4. It was found that there were significant protein changes in the process of callus formation and adventitious root formation. All protein points were numbered, and relative volume values of each protein point on different gels were obtained according to the method of protein differential cutting. Relative volume 1 and 2 are the relative ratios of protein volumes at $40 \mathrm{~d}$ and $20 \mathrm{~d}$ and $0 \mathrm{~d}$, respectively. After repeated comparison, eight protein points with a multiple of more than $10 \times$ or with a multiple of less than $0.1 \times$ were selected for functional identification. The results are shown in Table 1.

Proteins related to energy metabolism. Various ATP-related enzymes were identified in this experiment. ATP is direct energy necessary for physiologic metabolism in

Table 1. Homology analysis of the expressed proteins of different hardwood cuttings developing periods of Carya illinoinensis

\begin{tabular}{|c|c|c|c|c|c|c|}
\hline Spot & $\begin{array}{c}\text { Relative } \\
\text { volume } 1\end{array}$ & $\begin{array}{c}\text { Relative } \\
\text { volume } 2\end{array}$ & $\begin{array}{l}\text { Peptide } \\
\text { matches }\end{array}$ & Protein ID & Protein name & Organism matched \\
\hline S1 & 56.37 & 69.90 & 1 & gi|567889188 & Hypothetical protein CICLE_v10032743mg & Citrus clementina \\
\hline $\mathrm{S} 2$ & 46.02 & 1.75 & 3 & gi $\mid 6706286$ & Adenosine triphosphate synthase beta subunit & Phlox longifolia \\
\hline S3 & 21.83 & 1.05 & 1 & gi $\mid 255566325$ & Glutathione transferase & Ricinus communis \\
\hline S4 & 18.78 & 28.48 & 1 & gi| 657994221 & Predicted: probable inactive purple acid phosphatase 2 & Malus domestica \\
\hline S5 & 18.62 & 20.17 & 3 & gi| 568848242 & Predicted: heme-binding protein 2-like & Citrus sinensis \\
\hline S6 & 15.33 & 9.29 & 3 & gi $\mid 470142981$ & Stromal $70-\mathrm{kDa}$ heat shock-related protein & Fragaria vesca subsp. vesca \\
\hline S7 & 8.42 & 20.48 & 1 & gi $\mid 224075445$ & Transaldolase family protein & Populus trichocarpa \\
\hline S8 & 0.06 & 1.03 & 2 & gi| 255539693 & Enolase & Ricinus communis \\
\hline
\end{tabular}




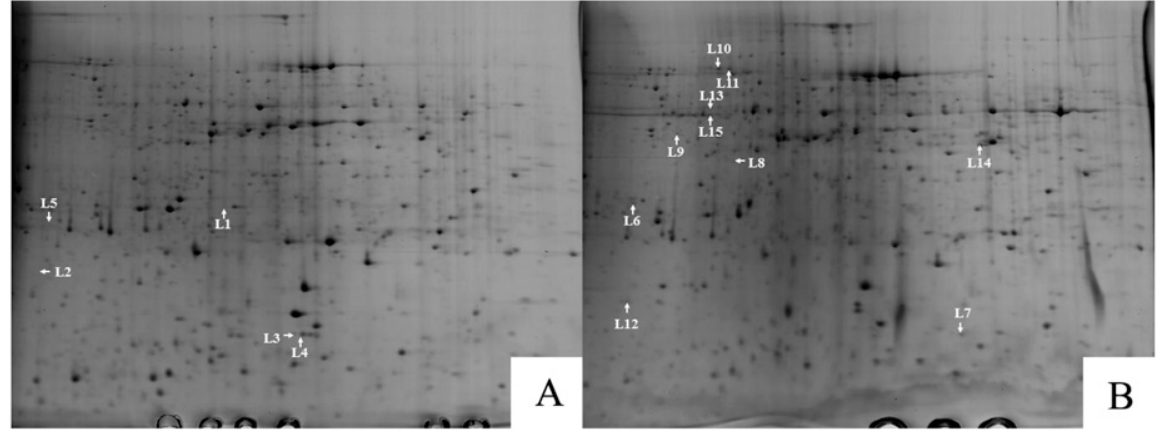

Fig. 5. Representative two-dimensional electrophoresis (2-DE) gel maps of proteins extracted from the pecan 'Pawnee' and 'Stuart' seedling hardwood cuttings on day 20 of the callus formation period. (A) 2-DE gel map of proteins extracted from the pecan hardwood cuttings of 'Pawnee'. L1 through L5 protein spots were greater than 10× expressed in this map. (B) 2-DE gel map of proteins extracted from the pecan hardwood cuttings of 'Stuart' seedlings. L6 through L15 protein spots were less than $0.1 \times$ expressed in this map. All 15 protein spots (L1-L15) were selected for homology analysis.

plants, providing energy for cell division and synthesis during the development of adventitious roots of spikelet. For instance, S2 is one ATP b group synthase (adenosine triphosphate synthase beta subunit); S4 is about phosphatase (Predicted: probable inactive purple acid phosphatase 2). It was found that, during the process of adventitious root formation, the spikelet was always in the state of needing a lot of energy, synthesizing and consuming ATP rapidly. Whether growth regulators can promote the activation of the ATP enzyme in cutting cells remains to be demonstrated in further tests.

In addition, S8 was identified as being similar to enolase. Enolase catalyzes the interconversion of 2-phosphoglyceric acid and phosphoenol-pyruvate, and is a key enzyme in glycolysis. Its expression level decreased during the formation of the unsteady pecan root in the United States, which showed substantial consumption of nutrients in the spikelet, and explains the reason for the formation of adventitious roots by selecting the plant with more nutrition.

Stress proteins. The stress protein identified in our study was S6 of heat shock protein (HSP). HSP is a kind of protein that responds to stress and is expressed in large quantities in organisms. It plays a key role in alleviating damage caused by high-temperature stress and improves plant resistance to high-temperature stress. HSP exists in almost all organisms, and its main structure is a conserved steroidal crystal protein domain consisting of $\approx 90$ amino acid residues. Adjacent to it is a variable n-terminal domain, which regulates oligosome formation, subunit kinetics, and its binding to substrates. Studies have found that HSPs not only protect the essential defense proteins in the basic physiologic process of plants, but also decompose damaged proteins and recycle the relevant materials for the synthesis of proteins so that the biochemical process in plant cells can continue.

The pecan hard-branch cutting experiment was conducted in an artificial climate, with a 20 to $25^{\circ} \mathrm{C}$ indoor temperature control and soil temperature control at 25 to $30^{\circ} \mathrm{C}$. The higher soil temperature affect the plant growth (Fan et al., 2017), in the test, which is conducive to callus formation in the cutting and the formation of adventitious roots. Therefore, electrothermal hotbed technology is widely used in the cutting production of difficult-to-root plants. We think that, with the induction of high soil temperatures, the phloem of the cuttings produces HSPs and improves the resistance of the cuttings.

There are many questions that need to be answered, such as whether the multiple HSPs can induce the rooting of calluses and the rooting of skin in cuttings, and whether HSPs can regulate the contents in cuttings. During adventitious root formation, identification of the function of HSPs can explain the electrothermal hotbed technology from the physiologic perspective, which is of great significance for guiding actual production.

Proteins related to electron transport. Two proteins related to electron transport were identified in our study. S1 is a protein of cytochromases and S5 is a protein of hemoglobin binding proteins. Cytochrome enzymes and hemoglobin proteins are electron transport proteins involved in the redox reaction in plants (Cao et al., 2016). As an electron carrier, cytochromase transmit electrons through the reduction and oxidation states of iron atoms and play an important role in energy transfer of plant cells. So far, there have been few reports on electron transport-related proteins during hardwood rooting, which needs to be studied further. How to regulate signal transmission and transduction proteins during spike adventitious root formation is a new area of interest.

Differential protein identification of pecan cultivar and seedling cuttings. The gel reviews of the treatment group and the control group are shown in Fig. 5. Pecan cultivar and seedling cuttings have obvious differences in protein expression. The number of expressions and difference multiples of each group are shown in Table 2, and the different multiples are the average expression of the processing group.

The difference between L1 and L5 is greater than 10. L1 was identified as perox- idase (POD). POD has two major functions in a plant. One is associated with normal plant formation during plant growth and development. Another function is related to the resistance of plants, which plays an important role in protecting plant enzymes. L2 was identified as peptidylprolyl isomerase. It plays an important role in protein folding settlement, which is also involved in protein complex assembly settlement, protein transport, and regulation of protein activity. L3 was identified as HSP. The main functions of the protein are maintenance of normal growth and plant development, the stress function, regulation of signal transduction protein activity, and the crossprotective effect (Wang et al., 2004). L4 was speculated to be 4-hydroxy-4-methyl-2oxoglutarate aldolase 2, and its specific function still needs to be identified. L5 was identified with the complex p-protein of mitochondrial glycine decarboxylase, which is modulated by light and plays an important role in light breathing (Chandok et al., 2003; Heineke et al., 2001).

The L6-L15 difference is less than 0.1, based on the results shown in Table 2. L6 was identified as fructose-1,6-bisphosphatase, cytosolic-like protein. This protein is a key enzyme in improving the efficiency of glucose phosphorylation and glucose metabolism (Massa et al., 2004). L7 is a protein similar to that of the optical system I ferric sulfide, which plays a role in photosynthesis - specifically, electron transport. Enolase (L8) is one of the key enzymes involved in glycolysis. L9 was identified as ribulose-1,5-bisphosphate carboxylase (Rubisco). L10 has been identified as a kinase. L11 (ATP-dependent zinc metalloproteinase FTSH 2) has ATP enzyme activity, proteolytic activity, and molecular partner activity. L12 has been identified as a member of the $20-\mathrm{kDa}$ partner protein family, which is similar to the homology of the family protein. L13 was identified as ketone alkyd reduction isomerase, which plays a role in the synthesis of amino acids in plant chloroplasts. L14 was identified as the latex plasmid-type family protein, which plays a role in glycolysis. L15 was identified as the disulfide isomerase family, which protects cells from oxidation and is associated with plant hormone transduction.

Pecan cuttings after $30 \mathrm{~d}$ exhibited massive callus formation in both the treatment group and the control group. However, after $40 \mathrm{~d}$, only the seedling cuttings of the control group began to form adventitious roots. 'Pawnee' cuttings could not form any roots because of nutrient depletion. During callus formation, the protective mechanism of plants was enhanced. HSP, for example, the former study of differential protein (S6) analysis during the key periods of seedling cutting rooting found that HSP from the callus formation stage to the stage of formation of adventitious root protein expression level was cut. In the protein analysis trial of different cutting types, the quantity of HSP expression of the treatment group compared with the control group was 25 -fold greater, 


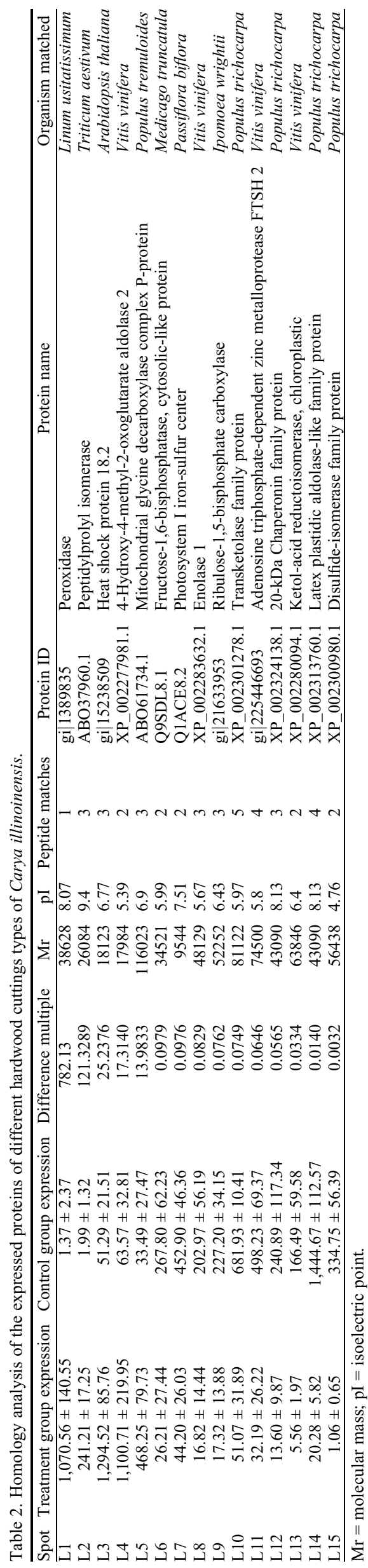

and there was very little POD expression. Most related proteins were related to energy metabolism. For example, to participate in glycolysis, enolase expression levels were elevated from the callus formation stage to the stage of formation of adventitious roots in the pecan seedling cuttings at different key stages. It has been speculated that the cultivar cuttings were still under the protection of the defense mechanism after they had formed calluses. Because the differentiation degree of cultivar cutting cells was much greater than that of the seedling cuttings, the period from the defense state to physiologic activation took longer. However, the embedded nutrients stored in the cuttings themselves were limited and incapable of providing adventitious roots. Another rooting limitation of cultivar cutting was morphologic structure. The cellular structure of the phloem of seedling and cultivar cuttings was different. Adventitious roots protruded primarily from the side of the expanded phloem instead of the base. Furthermore, their morphologic structure also affected the elongation and growth of adventitious roots. These inferences require further investigation.

Bottleneck of pecan cutting rooting. It is known that different temperature conditions impact plant growth. Different temperatures are widely used for pecan sprouting and cuttings in China (Zhang et al., 2015a). The rate of callus formation can reach more than $90 \%$, which shows that the callus is formed easier by a heated substrate. NAA treatment has a greater effect on differentiation instead of formation (Cao et al., 2016; Wu et al., 2016). All callus cells that break through the phloem developed from the base $(2-3 \mathrm{~cm})$. The base of the pecan hardwood cuttings was the place treated with NAA at $500 \mathrm{mg} \cdot \mathrm{L}^{-1}$ for $6 \mathrm{~h}$, indicating that the auxin in callus differentiation may play an important role. However, aside from morphologic and anatomic research, there are still many problems in pecan propagation from cuttings. First, the molecular mechanism of the adventitious root formation is unknown. Much research has focused on the plant rooting proteomics to show that proteomics is a useful tool, not only in finding rooting-related proteins and determining function in organ formation, but also as a means of identifying rooting ability of plants. The identification and function prediction of proteins should be studied further (Shang et al., 2012). Second, the effects of auxin on pecan hardwood cuttings require more research. It is known that the cuttings can get a strong rooting ability if treated with the appropriate volume of auxin. However, the transport process and signal pathway should be given more attention (Han et al., 2014). Third, the hardwood cuttings of the cultivar-grafted seedlings are very difficult to root. Most of the cutting materials are 1-year-old rootstocks from seeds instead of cultivars. Therefore, pecan hardwood cutting technology cannot currently be a popular application in production.

\section{Conclusions}

This study deduces that adventitious root formation of pecan hardwood cuttings was the product of callus differentiation only, which originated from the cells of the cambium or vascular ray parenchyma, and the adventitious root primordia were developed from those calluses that formed the regenerative structure. It also appears that the differentially expressed proteins of different periods during the adventitious rooting process of pecan seedling hardwood cuttings, which contained energy metabolism proteins (e.g., ATP b group synthase and phosphatase), adversity stress proteins (e.g., HSP), and signal transmission proteins (e.g., cytochromases and hemoglobin binding protein). However, more trials should be performed to identify methods to eliminate technologic bottlenecks of pecan cultivar cutting rooting.

\section{Literature Cited}

Allan, P., M. Brutsch, I. Smith, and B. Wolstenholme. 1980. Improved techniques for pecan propagation by hardwood cuttings. Pecan Qrtly. 14:7-14.

Brutsch, M., P. Allan, and B. Wolstenholme. 1969. Rooted pecan cuttings grown successfully in South Africa after first dormant period. Pecan Qrtly. 1:8-9.

Brutsch, M., P. Allan, and B. Wolstenholme. 1977. The anatomy of adventitious root formation in adult-phase pecan [Carya illinoinensis (Wang.) K. Koch] stem cuttings. Hort. Res. 17:23-31.

Bryant, P.H. and S.J. Trueman. 2015. Stem anatomy and adventitious root formation in cuttings of angophora, corymbia and eucalyptus. Forests 6:1227-1238

Cao, F., Y.-W. Liang, F.-R. Peng, Y.-R. Li, and M. Zhai. 2015. Research on hardwood cutting technology of Carya illinoinensis. J. Jiangsu For. Sci. Technol. 45:45-47.

Cao, F., F.-R. Peng, Y.-W. Liang, P.-P. Tan, K.-C. Wang, and L. Xin. 2016. Identification and function prediction of proteins during the adventitious rooting of pecan hardwood cuttings. J. Nanjing For. Univ. 40:53-58.

Carlson, M.C. 1938. The formation of nodal adventitious roots in Salix cordata. Amer. J. Bot. 25:721-725.

Carlson, M.C. 1950. Nodal adventitious roots in willow stems of different ages. Amer. J. Bot. 37:555-561

Casales, F.G., E. Van der Watt, and G.M. Coetzer. 2018. Propagation of pecan (Carya illinoinensis) A review. African J. Biotechnol. 17:586-605.

Chandok, M.R., A.J. Ytterberg, K.J. van Wijk, and D.F. Klessig. 2003. The pathogen-inducible nitric oxide synthase (iNOS) in plants is a variant of the $\mathrm{P}$ protein of the glycine decarboxylase complex. Cell 113:469-482.

Corte-Olivares, J., G.C. Phillips, and S. ButlerNance. 1990. Micropropagation of pecan. HortScience 25:1308

Davies, F., Jr., J. Lazarte, and J. Joiner. 1982 Initiation and development of roots in juvenile and mature leaf bud cuttings of Ficus pumila $\mathrm{L}$. Amer. J. Bot. 69:804-811.

Fan, G.-J., X. Wang, C.-E. Wu, H.-M. Pan, J.-T Yang, T.-T. Li, Z.-X. Tang, and F.-L. Cao. 2017. Effect of heating on the content and composition of ginkgolic acids in ginkgo seeds. Quality Assurance and Safety of Crops \& Foods 9:195-199. 
Fayek, M., A. Gomaa, F. Khalil, and E. El-Sayed. 1994. Anatomical studies on adventitious root of pecan stem cuttings. Zagazig J. Agr. Res. 21:487-500

Fouad, M., S. Abou-Taleb, B. Wood, and I. Yates. 1992. Propagation of pecan by stem and root cuttings. HortScience 27:691.

Han, H., X.-M. Sun, Y.-H. Xie, J. Feng, and S.-G. Zhang. 2014. Transcriptome and proteome profiling of adventitious root development in hybrid larch (Larix kaempferi $\times$ Larix olgensis). BMC Plant Biol. 14:305-319.

Heineke, D., N. Bykova, P. Gardeström, and H. Bauwe. 2001. Metabolic response of potato plants to an antisense reduction of the P-protein of glycine decarboxylase. Planta 212:880887.

Ma, J., R. Aloni, A. Villordon, D. Labonte, Y. Kfir, H. Zemach, A. Schwartz, L. Althan, and N. Firon. 2015. Adventitious root primordia formation and development in stem nodes of 'Georgia jet' sweetpotato, Ipomoea batatas. Amer. J. Bot. 102:1040-1049.

Massa, L., S. Baltrusch, D.A. Okar, A.J. Lange, S. Lenzen, and M. Tiedge. 2004. Interaction of 6phosphofructo-2-kinase/fructose-2, 6-bisphosphatase (PFK-2/FBPase-2) with glucokinase activates glucose phosphorylation and glucose metabolism in insulin-producing cells. Diabetes 53:1020-1029.

Mo, Z.-H., H.-Y. He, W.-C. Su, and F.-R. Peng. 2017. Analysis of differentially accumulated proteins associated with graft union formation in pecan (Carya illinoinensis). Scientia Hort. 224:126-134.

Peng, F.-R., Y.-R. Li, M.-Z. Hao, D.-L. Le, P.-P. Tan, and J.-Y. Zhang. 2012. The production situation and industrial development strategy of Carya illinoinensis in China. For. Sci. Technol. 26:1-4.

Sanderlin, R.S. 2015. Susceptibility of some common pecan rootstocks to infection by Xylella fastidiosa. HortScience 50:1183-1186.

Shang, X.-L., X.-Z. Xu, and S.-Z. Fang. 2012. Identification and quantitative analysis of germination inhibitors in the pericarp of Cyclocarpya paliurus (Batal) Iljinskaja. Propagation of Ornamental Plants 12:195-201.

Smith, M. and H. Chiu. 1980. Seasonal changes in the rooting of juvenile and adult pecan cuttings. HortScience 15:594-595.

Smith, C. and L. Romberg. 1939. A method for the treatment of cuttings and roots of the pecan with root-inducing chemicals. Plant Physiol. 14:177.

Wang, W., B. Vinocur, O. Shoseyov, and A. Altman. 2004. Role of plant heat-shock proteins and molecular chaperones in the abiotic stress response. Trends Plant Sci. 9:244 252.

Wolstenholme, B. and P. Allan. 1975. Progress and problems in pecan clonal propagation by stem cuttings Gewasproduksie/Crop Production 4: 29-32.
Wood, B.W. 2001. Production unit trends and price characteristics within the United States pecan industry. HortTechnology 11:110-118.

Wu, W.-H., F. Cao, Z.-Z. Liu, F.-R. Peng, Y.-W Liang, and P.-P. Tan. 2016. Effects of NAA treatment on the endogenous hormone changes in cuttings of Carya illinoinensis during rooting. J. Nanjing For. Univ. 40:191-196.

Zhang, J.-Y., Z.-R. Guo, R. Zhang, Y.-R. Li, L. Cao, Y.-W. Liang, and L.-B. Huang. 2015a. Auxin type, auxin concentration, and air and substrate temperature difference play key roles in the rooting of juvenile hardwood pecan cuttings. HortTechnology 25:209-213.

Zhang, R., F.-R. Peng, D.-L. Le, Z.-Z. Liu, H.-Y. He, Y.-W. Liang, P.-P. Tan, M.-Z. Hao, and Y.-R. Li. 2015b. Evaluation of epicotyl grafting on 25-to 55-day-old pecan seedlings. HortTechnology 25:392-396.

Zhang, R., F.-R. Peng, and Y.-R. Li. 2015c. Pecan production in China. Scientia Hort. 197:719727.

Zhang, M., D. Wang, H.-R. Tang, S.-X. Ren, and R.-D. Liu. 2010. Anatomical structure of stem and adventitious root formation of feijoa cuttings. Scientia Silvae Sinicae 46:183-187.

Zhou, H., C.-Z. Wang, J.-Z. Ye, H.-X. Chen, R. Tao, and F.-L. Cao. 2016. Effects of high hydrostatic pressure treatment on structural, allergenicity, and functional properties of proteins from ginkgo seeds. Innovative Food Science \& Emerging Technologies 34:187-195. 